Marquette University

e-Publications@Marquette

$2-1-2010$

The Duration of Foreclosures in the Subprime Mortgage Market: A Competing Risks Model with Mixing

Anthony Pennington-Cross

Marquette University, anthony.pennington-cross@marquette.edu

Accepted version. Journal of Real Estate Finance and Economics, Vol. 40, No. 2 (February 2010):

109-129. DOI. (C 2010 Springer Publishing Company. Used with permission.

Shareable Link. Provided by the Springer Nature SharedIt content-sharing initiative. 


\title{
The Duration of Foreclosures in the Subprime Mortgage Market: A Competing Risks Model with Mixing
}

\author{
Anthony Pennington-Cross \\ Department of Finance, Marquette University \\ Milwaukee, WI
}

\begin{abstract}
This paper examines what happens to mortgages in the subprime mortgage market once foreclosure proceeding are initiated. A multinomial logit model that allows for the interdependence of the possible outcomes or risks (cure, partial cure, paid off, and real estate owned) through the correlation of associated unobserved heterogeneities is estimated. The results show that the duration of foreclosures is impacted by many factors including contemporaneous housing market conditions, the prior performance of the loan (prior delinquency), and the state-level legal environment.
\end{abstract}

\section{Introduction}

Although a borrower is technically in default when a single payment is missed or late, lenders usually wait a substantial period of time, typically more than 90 days, before attempting to take possession of the property. ${ }^{-}$Lenders can take possession of property through foreclosure proceedings or through less adversarial approaches, such as deeds in lieu of foreclosure. For the vast majority of loans, the taking of property is not profitable for the lender. As a result, lenders make substantial efforts to delay or even forgo foreclosure and find alternative and less costly outcomes (Capozza and Thomson 2006). In addition, even after foreclosure proceedings have 
started, lenders and borrowers can work to find alternative outcomes which may impose a lower cost on either party.

However, a substantial fraction of subprime loans do enter foreclosure proceedings. For example, the Mortgage Bankers Association of America reports that over $9 \%$ of outstanding subprime loans were in foreclosure at some point during the 2000-2001 time period. In contrast, over the same time period, well under $1 \%$ of prime loans are in foreclosure. It is the time period when loans are in foreclosure that this paper focuses on. In particular the paper asks the question: What happens to subprime loans once foreclosure has been initiated by the lender? In particular, what is the probability that a loan in foreclosure today will eventually be in a state of cure (an active loans that is current or delinquent), prepaid, or will the lender become the owner of the property? The empirical investigation should help lenders make better decisions when processing loans in foreclosure and provide policy makers with clear avenues for improving the foreclosure process for everyone involved.

In general, of those loans that exit foreclosure and terminate the loan, almost $60 \%$ end up with the collateral property owned by the lender and $40 \%$ are paid off. Approximately $13 \%$ exit foreclosure but do not terminate and are either cured or partially (active, but delinquent) cured. The empirical approach uses a competing-risk discrete-mass-point mixed multinomial logit model specification. The results indicate that while many factors can impact the outcome of a loan in foreclosure, the policy makers and the resulting legal environment tend to dominate other factors. In particular, loans in states that require that the judicial system control the foreclosure proceedings tend to linger in foreclosure, while loans in states where foreclosure proceedings are completed under the power-of-sale tend to exit foreclosure much earlier through all available options (cure, collateral owned by the lender, or paid off).

This analysis provides a contribution to the literature in a number of ways. First, the length of foreclosure is examined in detail in the subprime market. Second, the type of exit is identified in a detailed loan-level data set of monthly observations of loans in foreclosure. Third, since most if not all the mortgage performance data sets have little information about the borrower, (for example, 
contemporaneous borrower employment, health status, or nonhousing wealth) the use of multinomial logit in the foreclosure literature is advanced by allowing for the interdependence of the potential exits (hazards or risks) from foreclosure through the correlation of associated, unobserved heterogeneities.

\section{Motivation and Literature}

One of the most widely studied topics in the mortgage finance literature is the termination of loans through borrower default. Typically default is treated as the time period when the foreclosure process is finished and the property has been sold. ${ }^{2}$ However, lenders attempt to recover any losses in a multiphase process once the borrower has stopped making payments. In particular, there is evidence that subprime loans tend to linger in delinquency for long periods before curing or terminating the loan. Capozza and Thomson (2006) find that subprime loans that are 90 days or more delinquent take four times longer to become Real Estate Owned (REO), but are much less likely to cure. In addition, Danis and Pennington-Cross (2005) find that subprime loans that linger in delinquency are much more likely to be prepaid than enter foreclosure proceedings. They interpret this type of prepayment as "distressed" prepayment because of the large payment that would be necessary to bring the status of the loan back to current (cured). Not surprisingly, given their extended period of serious delinquency, subprime loans tend to inflict larger losses than prime loans (Capozza and Thomson 2005).

Other studies have focused on the outcome of loans that are 90 days delinquent. For example, Ambrose and Capone (1998) follow more than 30,000 Federal Housing Authority (FHA)-insured loans until final resolution (reinstatement, property sale, assignment to the Department of Housing and Urban Development, and foreclosure). Loans are separated depending on the amount of equity in the home. Negative equity defaulters are viewed as "ruthless" because the value of the home is smaller that the value of the outstanding mortgage. As a result, it may make financial sense to default. Defaulters with positive equity are viewed as likely being "trigger event" defaulters. Trigger events are typically thought of as unexpected events that make it difficult for a household to continue making timely payments 
to service their current debt obligations. This includes job loss, a significant change in health status, and changes in family structure (divorce, in particular). If a household has used subprime lending, it is very unlikely that the household will have substantial resources to soften the impact of any trigger events. In fact, historically, the most popular product in subprime is the cash-out refinance, which is typically used to pay off other outstanding debt. Therefore, in subprime loans that are in default, they likely include many trigger event defaults and not ruthless defaults.

If foreclosure is an event that both borrowers and lenders would prefer to avoid, then conditions that make alternatives less costly, and hence more attractive, should be associated with lower REO rates and more lender forbearance. Various studies have found that contemporaneous economic conditions such as interest rates and house price appreciation can have substantial impacts on the disposition of a seriously delinquent loan (Ambrose and Capone 1998; Ambrose et al. 1997; Phillips and Vanderhoff 2004; Capozza Thomson 2005, 2006; Lambrecht et al. 2003; Phillips and Rosenblatt 1997). For example, if there is positive equity in a home, then the borrower can sell the house, pay off the debt, and avoid foreclosure. While the borrower may prefer to be a homeowner and not move, it may be less costly to move and sell the home than to be evicted. If interest rates have declined, it may also be possible for the borrower to refinance the loan and have more manageable monthly payments. $\underline{3}$

\section{Data}

The data consist of 5,000 loans that were originated over the calendar years 2001-2005. The time period of each loan's life under examination is the first month that the loan is reported as being in foreclosure until the loan terminates or December 2005 (whichever is first); $82 \%$ of the loans are observed to exit foreclosure over the observed time period. Of the exited loans, 50\% became lender REO property. While examining subprime loans over an 8 month time period, Capozza and Thomson (2005) found that $79 \%$ of defaulted loans (90 days or more delinquent) became REO property and the remaining $21 \%$ cured or prepaid. The $50 \%$ REO rate found in this study is likely to differ from the $79 \%$ REO rate because of different 
data sources (one lender versus a variety of lenders), different starting points (90 days delinquent versus in foreclosure), and different economic conditions. In addition, Phillips and Vanderhoff (2004) find that $30 \%$ of defaulted conventional fixed rate loans and $50 \%$ of defaulted conventional adjustable rate loans transition to REO and Ambrose and Capone $(\underline{1996}, \underline{1998})$ report that $32 \%$ to $38 \%$ of defaulted FHA loans transition to foreclosure. Therefore, the transition rates observed in this paper are similar to the high end of the conventional estimates and a little lower than the prior subprime estimate.

Loans in the foreclosure process can have other outcomes beyond REO. For example, the data shows that of the exited loans, on top of the $50 \%$ that became REO property, approximately $16 \%$ fully or partially cured, and the remaining $34 \%$ were paid off.

The paid off loans could cover all or only part of total obligation outstanding; however, in these cases the lender has fully terminated the loan and has taken the loss on any short (sale price < outstanding balance) sales or short prepayments. Since losses associated with owning property (REO) are reported to be over $50 \%$ of the outstanding debt obligation (Capozza and Thomson 2005), lenders may have strong incentives for avoiding real estate ownership and may be willing to accept short sales and prepayments as lower-cost substitutes. In fact, there is strong evidence that defaulted property depreciation is idiosyncratic and only partially driven by market-wide appreciation rates (Capozza and Thomson 2005; Pennington-Cross 2006).

The data, leased from LoanPerformance, are loans from their Asset Backed Securities data base. These are loans that are securitized in the private label market that have been identified and marketed in the secondary market as subprime loans. Fixed-rate 15- and 30-year owner-occupied for-purchase and refinance loans are included in the sample to help remove as much unobserved heterogeneity as possible from the sample and isolate the impact of contemporaneous economic conditions, legal conditions, and prior loan performance. The average loan size at origination is just over $\$ 112,000$ with a $15 \%$ down payment. The average Fair Isaac Corporation (FICO; consumer credit score) score was 604 and the average interest rate was over $9.3 \%$ and was approximately three percentage points above the prevailing 30 - 
year $(6.5 \%)$ and 15 -year $(6.0 \%)$ interest rates. Therefore, these loans are being charged a substantial premium by the mortgage market and the borrowers would likely have a difficult time securing prime rate credit because of relatively low credit scores. However, there are a few loans that have high credit scores included in the data set. These are likely still "subprime" for other reasons such as low or no documentation or other information was not included in the data set about the property or borrower. Often these loans are labeled "nonprime" or Alt-A loans.

Table 1 provides summary statistics and descriptions of the estimation data set. Each of the 5,000 loans is repeatedly observed in each month from the beginning of foreclosure until right censoring, termination through lender property ownership, or termination through the loan being paid off. Therefore, the average fraction of loans in each type of exit will be much lower than the cumulative numbers. For example, while $50 \%$ of observed loans exited foreclosure by terminating the loan, the average monthly rate of loan terminations through REO is $4 \%$ and the average monthly rate of loan terminations by being paid off is $3 \%$.

Various factors could impact whether a loan cures or terminates. For example, consider the time or months spent in foreclosure (months). As a loan spends more time in foreclosure the lender is incurring many costs including legal expenses and missed interest payments. In addition, the borrower has little incentive to maintain their property because they likely will no longer own the home. Consistent with this scenario Harding et al. (2000) find evidence that borrowers with loan to value (Itv) ratios of $100 \%$ spend less on maintenance than other homeowners. In addition, it takes time to process foreclosures. Therefore we should expect few exits early in the process and a higher probability of terminating the loan as the variable months increases.

The amount of equity is also likely to affect whether and in what manner the loan moves out of foreclosure. To measure equity the current loan-to-value ratio (cltv) is calculated using the unpaid balance of the loan in each month and the update house price using the Office of Federal Housing Enterprise Oversight metropolitan area repeat sales price index. In general, the more equity in the home the less costly it 
should be for the lender if the loan does become REO. However, the borrower may also have the opportunity to sell the house and pay off the loan in order to avoid being evicted. Since the borrower has the ability to move first by selling, this may be the primary type of termination when there is equity in the home. However, this will largely be an empirical question. Figure 1 provides the distribution of the estimated cltv at the beginning of the foreclosure process. It shows the expected peak of the distribution in the $75 \%$ to $80 \%$ cltvs. However, there is a lot of variation in homeowner equity. Table $\underline{2}$ plots the fraction of loans that are in each outcome type for a variety of cltv buckets at the last date of observation. It shows that large amounts of equity are usually associated with higher partial cure rates, full cure rates and paid off rates, while low and negative equity is associated with high rates of reo exit form foreclosure.

Other measures of economic and borrower conditions may impact foreclosures as well. For example, the prior behavior of the borrower may provide an indication about borrower behavior during foreclosure as well as how the lender may treat the foreclosure process. To measure prior behavior the Fair Isaacs fico score at origination of the loan and the fraction of loan months that the loan was delinquent (in-default) prior to the initiation of foreclosure proceedings (delinq) are included. Prior extensive delinquency (delinq) likely indicates that the lender or servicer has provided considerable forbearance in the past. If this pattern continues, then these loans may spend more time in foreclosure and be less likely to terminate through REO or being paid off. Because these loans are in foreclosure, borrowers with better credit scores are damaging their credit history during the foreclosure process. As a result, credit will be even more costly in the future and the household will likely lose their home. While this story is compelling it is an empirical question whether these circumstances lead to prolonged stays in foreclosure or toward any of the particular method of loan termination or curing. Table $\underline{2}$ provides some initial evidence supporting this theory using the raw data. For example, loans that have been delinquent for prolonged periods prior to the beginning of foreclosure and have low credit scores are more likely to partially cure, while those loans with much more brief periods of delinquency with higher credit scores are more likely to fully cure. Figures $\underline{2}$ and $\underline{3}$ also provide the distribution of credit scores and homeowner equity. FICO scorers look to be normally distributed 
around a peak in the 600 to 650 range. Delinquency (delinq) has a fatter right tail indicating that a significant proportion of loans linger for a long in the delinquent state before entering foreclosure.

Conditions in the housing and labor markets could also impact the outcome of a foreclosure. To proxy for labor market conditions, the state-level contemporaneous unemployment rate is included (unemp). In general, it may be more difficult for households to cure outstanding debts when labor market conditions are poor. Therefore, locations with higher unemployment rates are expected to be associated with lower probabilities of curing or partial curing. The extent that it is "in the money" to refinance is also included to proxy for interest impacts (refi). The present discounted value of the current mortgage is compared with the present discounted value of a market rate mortgage assuming that the term of the loan is not adjusted. ${ }^{4}$ The savings are reported as a fraction, so that 0.10 indicates that there is a $10 \%$ savings by refinancing before considering transaction costs. If interest rates have dropped, making it substantially "in the money" to refinance, the opportunity cost (rates on loans that could be made in the current month) of staying in foreclosure has become relatively lower from the lenders' perspective. In addition, if there is a fixed cost associated with some types of termination, loan size may also impact termination type.

Prior research has found that state foreclosure laws can affect the volume and pricing of mortgage lending (Pence 2003; Ambrose and Sanders 2005). The legal conditions under which the foreclosure proceeds are also likely to have strong impacts on the length or duration of the foreclosure spell. For example, states that require that foreclosures be processed through the court system (jud) are likely to extend the stay in foreclosure and retard any exit or termination. States that provide the statutory right of redemption (srr) are also likely to be associated with longer stays in foreclosure, because lenders typically wait until the end of the redemption period (which starts after the foreclosure auction) before attempting to take the property. 


\section{Competing-risk Mixed Multinomial Logit Model}

While this paper differs from the prior literature because it focuses on what happens to loans that are in the foreclosure process as opposed to loans that are 90 days delinquent, the empirical techniques used are very similar because there are multiple potential outcomes that need to be considered. The prior literature has largely used the multinomial logit model specification. This approach is extended by allowing for unobserved heterogeneity and the correlation of the associated unobserved heterogeneities. In the logit context these types of models are typically referred to as mixed logit models, or in our case, because of the multiple potential outcomes, mixed multinomial logit.

Logit models, both binomial and multinomial, have been widely used in reduced-form empirical models of mortgage termination. For instance, just in the study of 90-day-delinquent loans, recent examples include Ambrose and Capone (1998), Phillips and Vanderhoff (2004), Capozza and Thomson (2005, 2006), Phillips and Rosenblatt (1997). In each month the loan can be in only one state or outcome (delinquent, REO, prepaid, etc), so that by definition the multinomial logit model is a competing risks model. $\underline{5}$

Assume that there are $J, j=0, \ldots, J-1$, outcomes available and the vector of variables that explain the decision made for loan $\mathrm{i}$ is $x_{i}$. The probability $(\pi)$ of observing a particular loan outcome is given by

$$
\pi_{i j}=\frac{e^{\beta_{j}^{\prime} x_{i}}}{\sum_{k=0}^{J-1} e^{\beta_{k}^{\prime} x_{i}}} .
$$

The parameters, $\beta$, are normalized to zero for identification purposes. The other $\beta$ parameters are chosen to maximize the loglikelihood function

$$
\ln L=\sum_{i} \sum_{j=0}^{J-1} d_{i j} \ln \pi_{i j}
$$


where $d_{i j}$ is a dummy variable equal to 1 if $j$ is the outcome on loan $i$.

A drawback to the multinomial logit model is an undesirable property known as Independence from Irrelevant Alternatives (IIA). For any two alternatives $m$ and $n$, the ratio of the logit probabilities can be expressed as

$$
\frac{\pi_{i j}\left(Y_{i}=m\right)}{\pi\left(Y_{i}=n\right)}=\frac{e^{\beta_{m}^{\prime} x_{i}} / \sum_{k} e^{\beta_{k}^{\prime} x_{i}}}{e^{\beta_{n}^{\prime} x_{i}} / \sum_{k} e^{\beta_{k}^{\prime} x_{i}}}=e^{\beta_{m}^{\prime} x_{i}-\beta_{n}^{\prime} x_{i}} .
$$

This odds ratio for alternatives $\mathrm{m}$ and $\mathrm{n}$ do not depend upon any other alternatives. ${ }^{6}$ An alternative modeling strategy that partly solves this problem is to use nested logit models. Loan outcomes are partitioned into a tree structure. Each upper-level group is called a "branch," while each lower-level group of outcomes within a branch is called a "nest". The IIA property holds within nests but not between nests.

Similar to Clapp et al. (2006) the approach used in this paper is to take advantage of the unobserved heterogeneity and allow these heterogeneities to correlate. It is not possible to obtain loan-specific parameters to measure the impact of unobserved or random forces impacting the outcome. However, it is possible to capture the differences across loans by assuming that the heterogeneity follows some distribution (McFadden 1978; Wen and Koppelman 2001; Train 2003). The assumed distribution (common assumptions include normal, lognormal, triangular, and uniform) is estimated with the use of an additional parameter or parameters. However, if the a priori assumption about the shape of the distribution differs from the actual and unobserved underlying distribution, inferior solutions can be found (Heckman and Singer 1984). The approach used in this paper is to not assume a specific distribution and instead create groups of loans that have higher or lower likelihoods of terminating the loan or becoming cured. The technique cannot directly observe which group or mass point each loan belongs to and instead estimates a discrete probability distribution so that each group has a unique influence on the conditional monthly probability estimate. Each group of loans is identified by a mass point, representing a distinct mass of loans. The technique is estimated using maximum likelihood to obtain estimates 
of the size of each mass point and the idiosyncratic shift in the probability estimates. $\underline{7}$ When conditioning on observed and unobserved heterogeneities, the outcomes are assumed to be independent of each other. However, when conditioned only on observed heterogeneity each of the risks can become interdependent. This interdependence is created through the correlation of unobserved heterogeneities associated with each risk. The following defines the likelihood function including the unobserved heterogeneity.

$$
\begin{gathered}
\ln L=\sum_{i} \sum_{j=0}^{J-1} d_{i j} \ln \prod_{i j}, \\
\prod_{i j}=\sum_{m=1}^{M} p_{m} \pi_{i j m}, \\
\pi_{i j m}=\frac{e^{\beta_{j}^{\prime} x_{i}+v_{j m}}}{\sum_{k=0}^{J-1} e^{\beta_{k}^{\prime} x_{i}+v_{k m}}} .
\end{gathered}
$$

$U_{j m}$ are the location parameters that reflect the idiosyncratic risk for risk $j$ for the $m$ th unobserved heterogeneous group; $p_{m}$ is the mass-point parameter representing the proportion of loans in the $m$ th group; again, the parameters, $\beta$, are normalized to zero for identification purposes and the other $\beta$ parameters are chosen to maximize the log-likelihood function along with $U_{j m}$ and $p m$. Following Dong and Koppelman (2003) and Yu (2006) to ensure that the proportions lie within $[0,1]$ and sum to 1 , a logistic transformation is used on mass-point estimates.

$$
p_{m}=\left(e^{q_{m}} / \sum e^{q_{m}}\right)
$$

where $-\infty<q m<\infty$ and $q_{1}$ is normalized to 0 . 
Working from the bottom up, the equations define the likelihood function. Equation $\underline{6}\left(\Pi_{i j m}\right)$ defines the probability of outcome $j$ for loan $i$ given an unobserved group of $m$. Equation $\underline{5}\left(\Pi_{i j}\right)$ defines the probability of outcome $j$ for loan $i$ by summing $\Pi i j m$ across all the groups while weighting each group by $p$. Equation $\underline{4}(\ln L)$ defines the log of the likelihood by adding across all loans the log of the likelihood multiplied by outcome indictors $\left(\Sigma \Sigma d_{i j} \Pi_{i j}\right)$ so that only actual outcome contributes to the likelihood $\left(\Sigma \Sigma d_{i j} \Pi_{i j}\right)$.

\section{Results}

Table $\underline{3}$ provides the multinomial logit results with and without mixing. In general, both sets of reported results are similar in that coefficients for the exogenous variables are of similar size and direction. However, for some variables coefficient estimates can differ. For example, the impact of the local unemployment rate is lower on the results that do not include unobserved heterogeneity controls. Additionally, the coefficient is insignificant for curing without mixing but is significant and larger when mixing is allowed. There are also just as many instances when coefficient estimates become smaller in magnitude or become insignificant in the mixing specification. Prior duration analysis on other topics has also found that parameter estimates may be biased when unobserved heterogeneity is not controlled for (Deng et al. 2000).

The mixing parameter estimates are provided at the bottom of Table $3 . \underline{8}$ The mass-point estimate of 1.8245 undergoes a logistic transformation and indicates that approximately $86 \%$ of the loans are in group 1 and 14\% are in group 2. Group 1 includes loans with a relatively low probability of curing and a high probability of partial curing or being paid off. The estimates can be viewed as shifts up or down to the baseline function (to be discussed below). Using location parameters paid off outcome, if there is only one group, the location parameter is -2.84 ; but when two groups of loans are allowed through the mixing function, the parameters are 0.59 and -5.06 for groups 1 and 2, respectively. This indicates a large increase (decrease) in the probability of group 1 (group 2 ) terminating by being paid off. For the risk of terminating foreclosure through REO, there was no evidence of heterogeneity $\left(\mathrm{REO}_{2}\right.$ was insignificant at the $10 \%$ level). Therefore, the 
reported parameters include only one type of REO loan termination. This is why the parameter estimates for the REO risk type are very stable for the model specifications, both with and without mixing.

\section{Baseline}

The impact of the time the loan spends in foreclosure can be thought of as the baseline probability of leaving or exiting foreclosure and is measured by the variable months. Since the prior literature does not provide any guidance on the anticipated baseline, the results may be especially illuminating. $\frac{9}{}$ The variable months is positive and significant for all risks, indicating that the conditional monthly probability of leaving foreclosure increases relative to staying in foreclosure in each month for each potential risk. However, the positive coefficients do not indicate that the probability is increasing in each month (more details below) for all potential outcomes. All figures include the estimated probability (cumulative or conditional) holding all other variables at their means. For example, Fig. 4 provides a plot of the cumulative probability of a loan exiting foreclosure through REO or being paid off as the loan spends additional time, measured in months, in foreclosure holding all other variables at their means. The cumulative probability increases at a decreasing rate for both types of termination (REO and paid off). After 2.5 to 3 years, almost no additional loans exit through REO, while a few more exit by being paid off. This nonlinear baseline is further shown in Fig. $\underline{5}$, where the conditional (conditioned on being alive at the beginning of the month) monthly probability baseline reveals the relatively high (low) probability for REO exits when the loan has been in foreclosure for a short (long) time period. By the end of 3 years, over $80 \%$ of the loans have exited foreclosure through REO or have been paid off. The expected time spent in foreclosure for the typical subprime loan is approximately 11 months. The remainder of the loans are cured (partially or completely). 10 Therefore, while the probability of a loan curing may be important from a competing framework perspective, almost all loans that enter foreclosure exit through REO or are paid off. As a result, the remaining discussion will focus on these two outcomes. 
NOT THE PUBLISHED VERSION; this is the author's final, peer-reviewed manuscript. The published version may be accessed by following the link in the citation at the bottom of the page.

\section{Explanatory Variables}

Figures $\underline{6}, \underline{7}, \underline{8}, \underline{9}, \underline{10}$ and $\underline{11}$ plot the estimated conditional monthly probability of a loan exiting for each explanatory variable over the full range of observed values while holding all other variables constant. For example, consistent with Capozza and Thomson (2006) and Phillips and Vanderhoff (2004) Fig. $\underline{6}$ indicates that the probability of a loan exiting through REO is low (less than $1 \%$ ) when there is a lot of equity in the home and much higher when there is negative equity in the home (over 8\%). However, inconsistent with the prior literature, loans are more likely to exit foreclosure by being paid off when there is a lot of equity (up to 6\%) and less likely to terminate by being paid off when there is low or negative equity (less than $2 \%$ ). These results indicate that, although lenders would prefer to own property with positive equity, lenders are in practice most likely to own property when there is little or no equity and loss rates will be at their highest.

The results (Fig. $\underline{7}$ and Table $\underline{3}$ ) indicate that borrowers who had higher credit scores at origination are more likely to exit through REO or through being paid off and as a result are less likely to cure. Therefore, their duration in foreclosure is shorter. This is in contrast to Capozza and Thomson (2006) who found that the outcome for subprime loans in default was not strongly affected by borrower credit scores. While there may be many potential explanations, this result may indicate that borrowers with poor scores have different reasons for being seriously delinquent than those with better scores.

Higher area unemployment rates (Fig. $\underline{8}$ ) are associated with lower probabilities of exiting foreclosure through REO, thus leading to a longer stay in foreclosure. These results are consistent with the impact of local economic conditions on defaulted loan transitions into REO in both the subprime (Capozza and Thomson 2006) and conventional (Phillips and Vanderhoff 2004) mortgage markets. One interpretation of these results is that if a household does experience a reduction or stop in earnings, lenders may be patient in the hopes that the borrower will find gainful employment and start repaying the loan in the future. Therefore, the lender exercises more forbearance and the loan lingers in foreclosure. In fact, the probability of exiting foreclosure through REO of pay off decreases from just over $8 \%$ to 
NOT THE PUBLISHED VERSION; this is the author's final, peer-reviewed manuscript. The published version may be accessed by following the link in the citation at the bottom of the page.

approximately $5 \%$ for unemployment rates ranging from $1.5 \%$ to $10 \%$.

The delinquency of a loan before it enters foreclosure may also provide information on how the lender/servicer will proceed with foreclosures. The prior literature does not find any consistent results regarding indicators of prior payments and current performance once in default. This is likely due to the many different ways researchers have tried to measure past behavior of the loan. This paper's results indicate that loans that have been delinquent over longer periods prior to foreclosure are more likely to exit foreclosure through REO than through paying off the loan (Fig. ㅇ) . In fact, loans that were not delinquent for very long are approximately four times more likely to exit foreclosure through paying off the mortgage, while loans that have been delinquent almost their whole lives are almost four times more likely to exit foreclosure through REO. In addition, the probability of the loan being cured is very sensitive to the history of delinquency. For example, loans with short delinquency spells are very likely to become cured (probability of being in the cured state is over $50 \%$ per month), while loans that have been delinquent for long spells have an almost negligible probability of being cured (under 1\%). All of these results are consistent with the concept that lenders prefer not to be owners of property. As a result, property that ends up as REO come from loans where the borrower is in a state of distress (proxied by unemployment rates) or has pilling up large, unpaid bills and fees (proxied by time spent in serious delinquency).

Consistent with Capozza and Thomson (2006), in terms of interest rates, the results indicate that when interest rates have dropped, the probability of the loan being paid off decreases, while the probability of the loan becoming REO is unaffected (Fig. 10). In addition, loans are more likely to be cured in "down" interest rate environments. While the reasons for these findings may be unclear, the results may reflect small modifications or other methods of lender forbearance. Larger loans, as measured by the outstanding balance, are less likely to exit foreclosure through being paid off while smaller loans are more likely to exit foreclosure through REO (Fig. 11).

The impact of foreclosure laws on duration of foreclosure spells can be quite dramatic. For example, a loan in a power-of-sale state 
has a $53 \%$ higher probability of exiting foreclosure through REO than the average identical loan in a judicial foreclosure state. In addition, the probability of exiting foreclosure through paying off is also $28 \%$ higher. Phillips and VanderHoff (2004) also simulate a 50\% increase in the probability of foreclosure for power-of-sale proceedings and strongly suggest the need for regulatory reform to speed the foreclosure process. The findings in this paper echo prior finding and further indicate that power-of-sale proceedings not only increase the probability of exiting foreclosure through REO or paying off the loan, but also boost the probability of a loan in foreclosure to curing or partially curing. In contrast, states that allow a statutory right of redemption had almost no observable impact on the duration of foreclosure spells.

An alternative way to augment the baseline to reflect the speed of foreclosure is to directly include an estimate of the foreclosure speed for the state. A specification test was conducted using the average or typical number of months the initial foreclosure process takes (Clauretie and Sirmans 2006, p. 287) as an additional explanatory variable. However, since the average time for the initial process is largely determined by state foreclosure laws, the variables jud and srr cannot be included in the specification. The "months to complete initial action" variable performed as expected and had little impact on other variables' coefficient estimates. For example, states with longer foreclosure proceedings all have lower probabilities of exiting foreclosure through any method (curing, partial curing, REO, of pay off). 11

\section{Conclusion}

This research examines a unique data set of subprime loans that are in foreclosure. The data allows the monthly observation of the loan until the loan terminates. Loans can exit foreclosure through curing, partially (delinquent) curing, becoming REO property, or paying off the outstanding balance on the loan (paid off). For loans that are in foreclosure for a relatively short time period (less than a year) the primary way to exit foreclosure is through REO; but, as the time in foreclosure lengthens, paying off the loan becomes the dominate way to exit. 
Consistent with the findings of Ambrose and Capone (1998), the results of this paper indicate that loans in foreclosure include borrowers who are exercising the put option and those who may be using extended periods of nonpayment to finance other expenditures or receive temporary free rent. In the data, approximately $40 \%$ of the loans were terminated through REO whereas $27 \%$ were terminated through paying off the loan. In contrast, $13 \%$ of the loans were successfully cured or partially cured.

The composite conditions that lead to the lender becoming the owner of the underlying property are-early exit of foreclosure, low or no equity left in the property either due to a low initial down payment or declining property values, a relatively high borrower credit score for subprime, a long history of delinquency before foreclosure begins, declining interest rates, a smaller loan amount or loan balance, and the property being located in a state with power-of-sale foreclosures.

In conjunction with prior literature, the behavior of troubled loans in the subprime market is also becoming clearer. Subprime loans tend to linger for long periods when the loan is behind in its payments, but once the foreclosure process has begun, subprime loans proceed on a more typical pace. For example, Capozza and Thomson (2006) estimate that it can take 6.5 years for a seriously delinquent subprime loan to transition to foreclosure. In contrast, for seriously delinquent FHA loans, Ambrose and Capone (1996) find an average duration of only 7.5 months. The results found here indicate that the expected time spent in foreclosure for the typical subprime loan is approximately 11 months.

Subprime loans are also more likely to exit foreclosure with the lender becoming the owner of the underlying property. Consistent with the perception that foreclosures are the least preferred and most expensive method of resolving a problem loan, both seriously delinquent (Capozza and Thomson 2006) and loans in foreclosure are more likely to be paid off if there is more equity in the home foreclosure. In addition, while some loans may cure even after foreclosure proceedings have started, the vast majority will eventually terminate the loans through REO or paying off the loan. 
While prior evidence indicated that subprime loans tend to linger for long periods in serious delinquency, the results in this paper indicate that this pattern of behavior is not without a cost. In particular, loans that have experienced substantial forbearance in the past are more likely to become REO property if they enter foreclosure.

The results of this paper also indicate the need for reform of the legal process used to adjudicate foreclosure proceedings in many states. In particular, relative to states that require a judicial foreclosure, power-of-sale states are associated with large increases in the conditional monthly probability of curing (30\% to $65 \%$ higher) and terminating through REO or paying off the loan ( $28 \%$ to $45 \%$ higher). Therefore, foreclosures in power-of-sale states take much less time to complete, but can also increase the likelihood of the loan curing. In total, in power-of sale states a loan in foreclosure is more likely to have a superior outcome for both the lender and the borrower.

\section{Endnotes}

1 The reason lenders wait until after 90-days delinquency to start foreclosure proceedings is a hold-over from English common law called "equity of redemption." The intent is to delay the taking of the property or the initiation of that process because the taking of someone's home is an action with substantial and serious consequences.

2 Note that typically the lender "buys" the property and it becomes owned by the lender or "real estate owned". Then the lender sells the property in an attempt to recoup as much of the losses as possible.

$\underline{3}$ Another tool that could be used to reduce debt servicing requirements is to refinance into a loan with a longer repayment period or an adjustable rate loan.

4 The Freddie Mac Primary Mortgage Market Survey (PMMS) is used to proxy for prevailing interest rates on mortgages. Since these are subprime loans with risk premiums, the risk premium of the loan at origination is used to adjust up the PMMS rate to create a comparable market rate. 
$\underline{5} \mathrm{~A}$ risk in this context reflects the types of outcome (termination or cure) in each month that compete to be observed.

$\underline{6} \mathrm{~A}$ well-known example illustrates a problem with this assumption. A traveler has a choice of going to work by car or by a blue bus. Let the choice probabilities be equal, implying the ratio of probabilities equals 1 . Now introduce a choice of a red bus that the traveler considers equivalent to a blue bus. We would expect the probability of going to work by car to remain the same at 0.5 , while the probabilities of going to work by bus would be split evenly between blue and red buses at 0.25 . If this were true, then the ratio of probabilities between car and blue bus, formerly at 1 , would now be equal to 2 ( 0.5 divided by 0.25 ). The multinomial logit model does not allow this possibility. Recall that there are equal probabilities of taking a blue bus and a red bus. The only profile of probabilities that fit these two constraints puts equal probability of 0.33 on each choice. The multinomial logit would therefore overestimate the probability of taking a blue or a red bus and would underestimate the probability of taking a car.

7 The likelihood function is maximized in SAS using Proc NLP, and the code is available on request from the author.

$\underline{8}$ During estimation at most two mass points could be identified. Attempts to estimate with three mass-points could not converge or drove the size of one group to almost zero.

9 Phillips and VanderHoff (2004) do include a variable called defaulttime, but they only analyze the last observed outcome in their sample. Therefore, it is difficult to create or interpret a baseline estimate.

10 The conditional monthly probability of curing or partially curing is over $89 \%$ in the 37 th month.

11 Replacing jud and srr with "months to complete initial action" the coefficient estimates for each outcome are cure $(-0.144439)$, partial cure $(-0.535416)$, REO $(-0.251730)$, paid off 
NOT THE PUBLISHED VERSION; this is the author's final, peer-reviewed manuscript. The published version may be accessed by following the link in the citation at the bottom of the page.

$(-0.421515)$. The mean "months to complete initial action" is 4.84 months ranging from 1 to 9 months.

\section{About the Author}

- Corresponding author: A. Pennington-Cross: Department of Finance, Marquette University, Straz Hall, 328, P.O. Box 1881, Milwaukee, WI 53201-1881, USA, e-mail: anthony.pennington-cross@mu.edu

\section{Acknowledgements}

This research was started while the author was affiliated with the Federal Reserve Bank of St. Louis and the views expressed in this research are those of the individual author and do not necessarily reflect the official positions of the Federal Reserve Bank of St. Louis, the Federal Reserve System, or the Board of Governors.

\section{References}

Ambrose, B., \& Capone, C. (1996). Do lenders discriminate in processing defaults. Cityscape, 2(1), 89-98.

Ambrose, B., \& Capone, C. (1998). Modeling the conditional probability of foreclosure in the context of single-family mortgage default resolutions. Real Estate Economics, 26(3), 391-429.

Ambrose, B., \& Capone, C. (2000). The hazard rates of first and second defaults. Journal of Real Estate Finance and Economics, 20(3), 275293.

Ambrose, B., \& Sanders, A. (2005). Legal Restrictions in Personal Loan Markets. Journal of Real Estate Finance and Economics, 30(2), 133151.

Ambrose, B., Buttimer, R., \& Capone, C. (1997). Pricing mortgage default and foreclosure delay. Journal of Money, Credit, and Banking, 29(3), 314325.

Capozza, D., \& Thomson, T. (2005) Optimal stopping and losses on subprime mortgages. Journal of Real Estate Finance and Economics, 30(2), 115131. 
NOT THE PUBLISHED VERSION; this is the author's final, peer-reviewed manuscript. The published version may be accessed by following the link in the citation at the bottom of the page.

Capozza, D., \& Thomson, T. (2006). Subprime transitions: Lingering or malingering in default? Journal of Real Estate Finance and Economics, $33(3), 241-258$.

Clapp, J., Deng, Y., \& An, X. (2006). Unobserved heterogeneity in models of competing mortgage termination risks. Real Estate Economics, 34(2), 243-273.

Clauretie, T. M., \& Sirmans, G. S. (2006). Real estate finance: Theory and practice, (5th ed., p. 287). Mason: Thomson South-Western Publishing.

Danis, M., \& Pennington-Cross, A. (2005). A dynamic look at subprime loan performance. The Journal of Fixed Income, 15(1), 28-39.

Deng, Y., Quigley, J., \& Van Order, R. (2000). Mortgage termination, heterogeneity, and the exercise of mortgage options. Econometrica, $68(2), 275-307$.

Dong, X., \& Koppelman, F. S. (2003). Comparison of methods representing heterogeneity in logit models. Presented at the 10th International Conference on Travel Behaviour Research, Lucerne, 10-15 August 2003.

Harding, J., Miceli, T., \& Sirmans, C. F. (2000). Deficiency Judgments and Borrower Maintenance: Theory and Evidence. Journal of Housing Economics, 9(4), 267-85.

Heckman, J., \& Singer, B. (1984). A method for minimizing the impact of distributional assumptions in econometric models of duration data. Econometrica, 52(2), 271-320.

Lambrecht, B., Perraudin, W., \& Satchell, S. (2003). Mortgage default and possession under recourse: A competing hazards approach. Journal of Money, Credit, and Banking, 35(3), 425-442.

McFadden, D. (1978). Modeling the choice of residential location. In A. Karlquist et al (Ed.), Spatial interaction theory and residential location (pp. 75-96). Amsterdam: North-Holland.

Pence, K. M. (2003). Foreclosing on opportunity: State laws and mortgage credit. Board of Governors of the Federal Reserve System (U.S.), Finance and Economics Discussion Series: 2003-16.

Journal of Real Estate Finance and Economics, Vol. 40, No. 2 (February 2010): pg. 109-129. DOI. This article is (C) Springer and permission has been granted for this version to appear in e-Publications@Marquette. Springer does not grant permission for this article to be further copied/distributed or hosted elsewhere without the express permission from Springer. 
NOT THE PUBLISHED VERSION; this is the author's final, peer-reviewed manuscript. The published version may be accessed by following the link in the citation at the bottom of the page.

Pennington-Cross, A. (2006). The value of foreclosed property. Journal of Real Estate Research, 28(2), 193-214.

Phillips, R., \& Rosenblatt, E. (1997). The legal environment and the choice of default resolution alternatives: An empirical analysis. Journal of Real Estate Research, 13(2), 145-154.

Phillips, R. A., \& Vanderhoff, J. H. (2004). The conditional probability of foreclosure: An empirical analysis of conventional mortgage loan defaults. Real Estate Economics, 32(4), 571-588.

Train, K. (2003). Discrete choice methods with simulation. Cambridge: Cambridge University Press.

Wen, C.-H., \& Koppelman, F. S. (2001). The generalized nested logit model. Transportation Research: Part B: Methodological, 35(7), 627-641.

Yu, X. (2006). Competing risk analysis of Japan's small financial institutions. Stanford University, Department of Economics Working Paper.

\section{Appendix}

Table 1 Descriptive statistics

\begin{tabular}{|c|c|c|c|c|c|}
\hline Variable & Mean & $\begin{array}{l}\text { Std. } \\
\text { Dev. }\end{array}$ & Min. & Max. & Description \\
\hline Foreclose & 0.62 & 0.48 & 0 & 1 & Loan in foreclosure proceedings \\
\hline Cure & 0.15 & 0.36 & 0 & 1 & Loan current \\
\hline Partial cure & 0.16 & 0.37 & 0 & 1 & Loan delinquent \\
\hline REO & 0.04 & 0.19 & 0 & 1 & Property is real estate owned by the lender \\
\hline Paid offa & 0.03 & 0.16 & 0 & 1 & Loan paid off \\
\hline Months & 10.07 & 8.79 & 1 & 52 & Months in foreclosure \\
\hline Cltv & 72.15 & 13.91 & 10.19 & 108.9 & $\begin{array}{l}\text { Current loan to value ratio calculated using } \\
\text { actual balance and the updated house price } \\
\text { using state level OFHEO HPI }\end{array}$ \\
\hline Fico & 603.84 & 58.67 & 417 & 818 & Fair Isaac credit score at loan origination \\
\hline Unemp & 5.41 & 1.37 & 2.1 & 26.2 & $\begin{array}{l}\text { State unemployment rate in the current } \\
\text { month collected from the Bureau of Labor } \\
\text { Statistics }\end{array}$ \\
\hline Delinq & 0.49 & 0.24 & 0.02 & 1 & $\begin{array}{l}\text { Share of months loan was delinquent prior } \\
\text { to when the foreclosure was initiated }\end{array}$ \\
\hline Refi & 0.08 & 0.07 & -0.19 & 0.89 & $\begin{array}{l}\text { Fraction "in the money" to refinance due to } \\
\text { market wide interest rate changes }\end{array}$ \\
\hline Upb & 10.67 & 9.03 & 1.20 & & $\begin{array}{l}\text { Outstanding or unpaid balance }(\$ 10,000 \text { 's) } \\
\text { on the loan in each month }\end{array}$ \\
\hline
\end{tabular}

Journal of Real Estate Finance and Economics, Vol. 40, No. 2 (February 2010): pg. 109-129. DOI. This article is (C) Springer and permission has been granted for this version to appear in e-Publications@Marquette. Springer does not grant permission for this article to be further copied/distributed or hosted elsewhere without the express permission from Springer. 
NOT THE PUBLISHED VERSION; this is the author's final, peer-reviewed manuscript. The published version may be accessed by following the link in the citation at the bottom of the page.

\begin{tabular}{|l|l|l|l|l|l|}
\hline Variable & Mean & $\begin{array}{l}\text { Std. } \\
\text { Dev. }\end{array}$ & Min. & Max. & Description \\
\hline Jud & 0.55 & 0.50 & 0 & 1 & $\begin{array}{l}\text { Judicial foreclosure state = 1, and power-of- } \\
\text { sale state = 0 (Pence 2003) }\end{array}$ \\
\hline Srr & 0.12 & 0.33 & 0 & 1 & $\begin{array}{l}\text { Statutory right of redemption state =1, and } \\
\text { non-redemption state = 0 (Pence 2003) }\end{array}$ \\
\hline Loans & 5,000 & & & & Number of loans \\
\hline Observations & 53,924 & & & & Number of loan-months \\
\hline
\end{tabular}

aLoans can be paid off for a variety of reasons including, selling the home, third-party sales at the foreclosure auction, refinancing into a new loan, etc.

Table 2. Outcome by variable and category

\begin{tabular}{|c|c|c|c|c|}
\hline \multirow{2}{*}{ Variable/category } & \multicolumn{4}{|c|}{ Outcome Type } \\
\hline & Cure (\%) & Partial cure (\%) & REO (\%) & Paid off (\%) \\
\hline \multicolumn{5}{|l|}{ FICO } \\
\hline FICO $\leq 500$ & 4 & 20 & 36 & 27 \\
\hline $500<\mathrm{FICO} \leq 550$ & 9 & 11 & 38 & 27 \\
\hline $550<\mathrm{FICO} \leq 600$ & 7 & 9 & 38 & 27 \\
\hline $600<\mathrm{FICO} \leq 650$ & 7 & 5 & 43 & 26 \\
\hline $650<$ FICO $\leq 700$ & 5 & 4 & 43 & 30 \\
\hline $700<\mathrm{FICO} \leq 750$ & 2 & 2 & 45 & 36 \\
\hline $750<$ FICO & 5 & 1 & 39 & 39 \\
\hline \multicolumn{5}{|l|}{$L T V_{t=T}$} \\
\hline$L T V_{t=T} \leq 40$ & 28 & 10 & 6 & 42 \\
\hline $40<L T V_{t=T} \leq 50$ & 20 & 14 & 6 & 34 \\
\hline $50<L T V_{t=T} \leq 60$ & 10 & 12 & 16 & 38 \\
\hline $60<L T V_{t=T} \leq 70$ & 9 & 10 & 30 & 31 \\
\hline $80<L T V_{t=T} \leq 90$ & 3 & 5 & 50 & 24 \\
\hline $90<L T V_{t=T} \leq 100$ & 4 & 3 & 55 & 22 \\
\hline$L T V_{t=T}>100$ & 1 & 1 & 59 & 26 \\
\hline \multicolumn{5}{|c|}{ Delinquency history } \\
\hline DELINQ $\leq 10$ & 31 & 1 & 3 & 43 \\
\hline $10<$ DELINQ $\leq 20$ & 17 & 4 & 21 & 37 \\
\hline $20<$ DELINQ $\leq 30$ & 11 & 5 & 35 & 31 \\
\hline $30<$ DELINQ $\leq 40$ & 6 & 5 & 41 & 32 \\
\hline $40<$ DELINQ $\leq 50$ & 6 & 5 & 48 & 26 \\
\hline $50<$ DELINQ $\leq 60$ & 4 & 7 & 48 & 23 \\
\hline $60<$ DELINQ $\leq 70$ & 3 & 6 & 48 & 24 \\
\hline $70<$ DELINQ $\leq 80$ & 1 & 10 & 46 & 24 \\
\hline DELINQ $>80$ & 1 & 17 & 43 & 20 \\
\hline
\end{tabular}

The numbers indicate the percent of loans on their last observed date are in each outcome. These results are not model generated and reflect the "raw" data from the sample. FICO is the Fair Isaac's consumer credit score at origination of the loan. LTV $t$ $=T$ is the estimated loan to value ratio on the last date observed. Deling is the fraction of the loan's life spent in delinquency prior to the beginning of foreclosure proceedings

Journal of Real Estate Finance and Economics, Vol. 40, No. 2 (February 2010): pg. 109-129. DOI. This article is (C Springer and permission has been granted for this version to appear in e-Publications@Marquette. Springer does not grant permission for this article to be further copied/distributed or hosted elsewhere without the express permission from Springer. 
Table 3. Multinomial logit results

\begin{tabular}{|c|c|c|c|c|c|}
\hline \multirow{2}{*}{ Risk } & \multirow{2}{*}{ Variable } & \multicolumn{4}{|c|}{ Without mixing With mixing } \\
\hline & & Coeff. & Std Err & Coeff. & Std Err \\
\hline \multirow{9}{*}{ Cure } & Months & $0.1508^{a}$ & 0.0022 & $0.1651^{a}$ & 0.0026 \\
\hline & Ltvc & $-0.0179 a$ & 0.0011 & $-0.0182^{a}$ & 0.0012 \\
\hline & FICO & $-0.0038^{a}$ & 0.0003 & $-0.0038^{a}$ & 0.0003 \\
\hline & Unemp & 0.0148 & 0.0101 & $0.0265^{a}$ & 0.0107 \\
\hline & Delinq & $-7.6200^{a}$ & 0.0975 & $-8.3110^{a}$ & 0.1167 \\
\hline & Refi & $-0.9498^{a}$ & 0.2206 & $-1.1439^{a}$ & 0.2306 \\
\hline & Upb & $0.0057^{a}$ & 0.0018 & $0.0064^{a}$ & 0.0018 \\
\hline & Jud & $-0.7043^{a}$ & 0.0318 & $-0.6488^{a}$ & 0.0340 \\
\hline & Srr & -0.0331 & 0.0476 & -0.0232 & 0.0500 \\
\hline \multirow{9}{*}{ Partial cure } & Months & $0.0829^{a}$ & 0.0018 & $0.0906^{a}$ & 0.0029 \\
\hline & Ltvc & $-0.0059^{a}$ & 0.0010 & $-0.0076^{a}$ & 0.0014 \\
\hline & FICO & $-0.0056^{a}$ & 0.0003 & $-0.0066^{\mathrm{a}}$ & 0.0004 \\
\hline & Unemp & $-0.0341^{a}$ & 0.0097 & $-0.0522^{a}$ & 0.0126 \\
\hline & Delinq & 0.0382 & 0.0690 & $0.6333^{a}$ & 0.1182 \\
\hline & Refi & 0.1380 & 0.1948 & 0.1709 & 0.2522 \\
\hline & Upb & -0.0020 & 0.0015 & -0.0013 & 0.0021 \\
\hline & Jud & $-1.4575^{a}$ & 0.0288 & $-1.9194^{a}$ & 0.0858 \\
\hline & Srr & $0.0975^{a}$ & 0.0379 & $0.1205^{a}$ & 0.0491 \\
\hline \multirow{9}{*}{ REO } & Months & $0.0203^{a}$ & 0.0039 & $0.0208^{a}$ & 0.0039 \\
\hline & Ltvc & $0.0246^{a}$ & 0.0021 & $0.0249^{a}$ & 0.0021 \\
\hline & FICO & $0.0008^{b}$ & 0.0004 & $0.0008^{b}$ & 0.0004 \\
\hline & Unemp & $-0.0687^{a}$ & 0.0192 & $-0.0683^{\mathrm{a}}$ & 0.0192 \\
\hline & Delinq & -0.1527 & 0.1210 & -0.1414 & 0.1226 \\
\hline & Refi & -0.0266 & 0.3524 & -0.0289 & 0.3522 \\
\hline & Upb & $-0.0153^{a}$ & 0.0032 & $-0.0155^{a}$ & 0.0032 \\
\hline & Jud & $-1.0888^{a}$ & 0.0503 & $-1.0963^{a}$ & 0.0505 \\
\hline & Srr & 0.0045 & 0.0661 & 0.0034 & 0.0662 \\
\hline \multirow{9}{*}{ Paid off } & Months & $0.0706^{a}$ & 0.0041 & $0.0735^{\mathrm{a}}$ & 0.0056 \\
\hline & Ltvc & $-0.0201^{a}$ & 0.0020 & $-0.0234^{a}$ & 0.0030 \\
\hline & FICO & $0.0017^{a}$ & 0.0005 & -0.0004 & 0.0008 \\
\hline & Unemp & $-0.0575^{a}$ & 0.0211 & $-0.0945^{a}$ & 0.0264 \\
\hline & Delinq & $-2.6305^{a}$ & 0.1564 & $-1.1865^{a}$ & 0.2391 \\
\hline & Refi & $-2.2496^{a}$ & 0.4091 & $-2.3367^{a}$ & 0.5354 \\
\hline & Upb & $0.0139^{a}$ & 0.0023 & $0.0180^{a}$ & 0.0052 \\
\hline & Jud & $-0.7143^{a}$ & 0.0597 & $-1.6382^{a}$ & 0.1727 \\
\hline & Srr & 0.0401 & 0.0837 & 0.1018 & 0.1125 \\
\hline Mass point & Mass $_{1}$ & & & $1.8245^{\mathrm{a}}$ & 0.0991 \\
\hline \multirow{7}{*}{ Location } & Cure $_{1}$ & $-1.7399^{a}$ & 0.0279 & $-4.2005^{a}$ & 0.4950 \\
\hline & Cure $_{2}$ & & & $-1.7844^{a}$ & 0.0301 \\
\hline & Partial cure & $-0.7441^{a}$ & 0.0200 & $1.8730^{\mathrm{a}}$ & 0.2046 \\
\hline & Partial cure & & & $-1.2842^{\circ}$ & 0.0773 \\
\hline & $\mathrm{REO}_{1}$ & $-2.3051^{a}$ & 0.0365 & $-2.3012^{a}$ & 0.0366 \\
\hline & Paid off 1 & $-2.8371^{a}$ & 0.0458 & $0.5867^{b}$ & 0.2865 \\
\hline & Paid off 2 & & & $-5.0635^{a}$ & 1.1941 \\
\hline
\end{tabular}

Journal of Real Estate Finance and Economics, Vol. 40, No. 2 (February 2010): pg. 109-129. DOI. This article is (C) Springer and permission has been granted for this version to appear in e-Publications@Marquette. Springer does not grant permission for this article to be further copied/distributed or hosted elsewhere without the express permission from Springer. 
NOT THE PUBLISHED VERSION; this is the author's final, peer-reviewed manuscript. The published version may be accessed by following the link in the citation at the bottom of the page.

All continuous variables are mean deleted for estimation. The second group for the REO location parameter was insignificant and therefore not included in the final specification. A logistic transformation is used for the reported mass point coefficients

aSignificant at $1 \%$

bSignificant at $10 \%$

Figure 1. Distribution of LTV. LTV is the estimated loan to value ratio at beginning of foreclosure proceedings

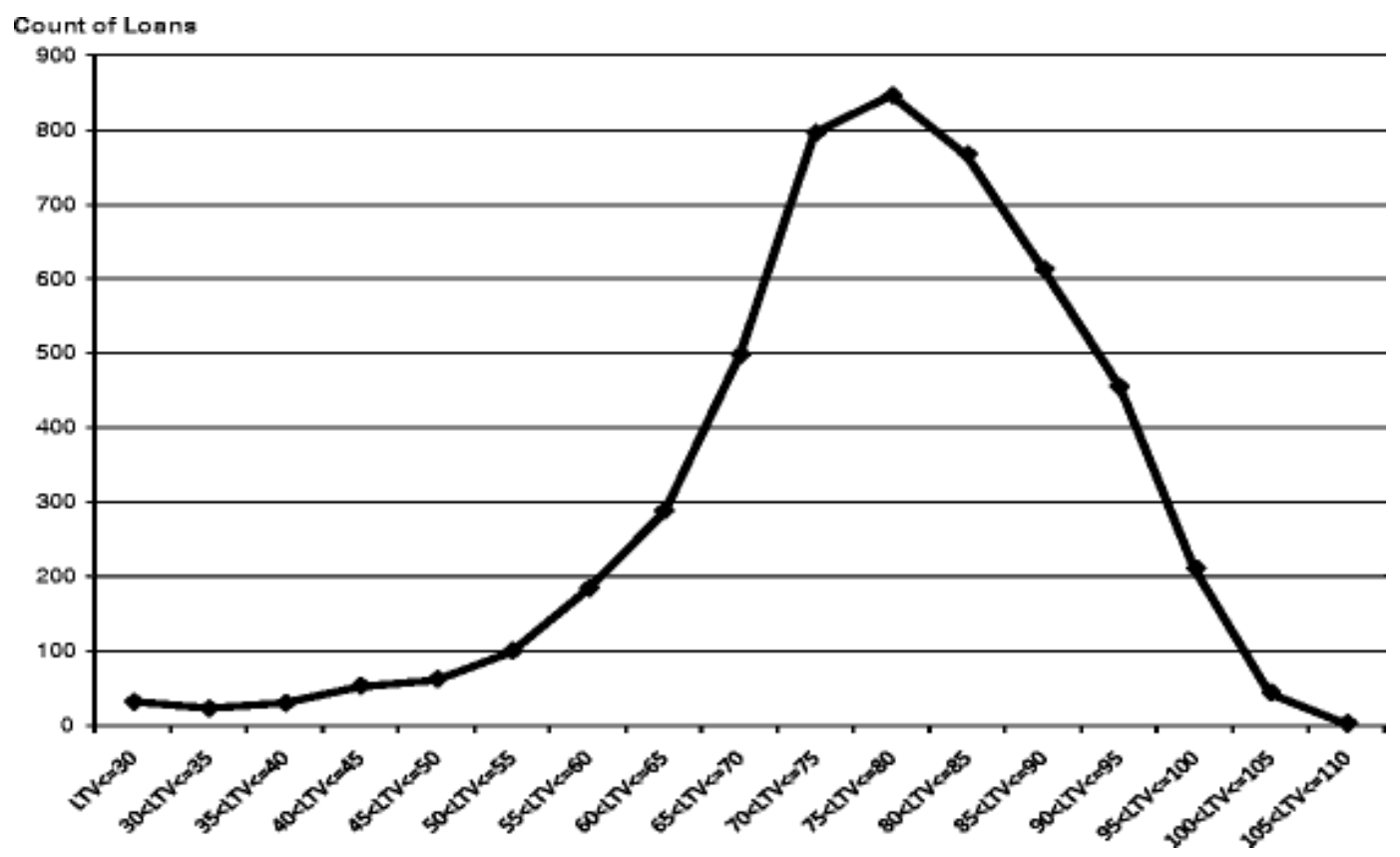

Figure 2. Distribution of FICO score. FICO is the Fair Isaac's consumer credit score at origination of the loan 
NOT THE PUBLISHED VERSION; this is the author's final, peer-reviewed manuscript. The published version may be accessed by following the link in the citation at the bottom of the page.

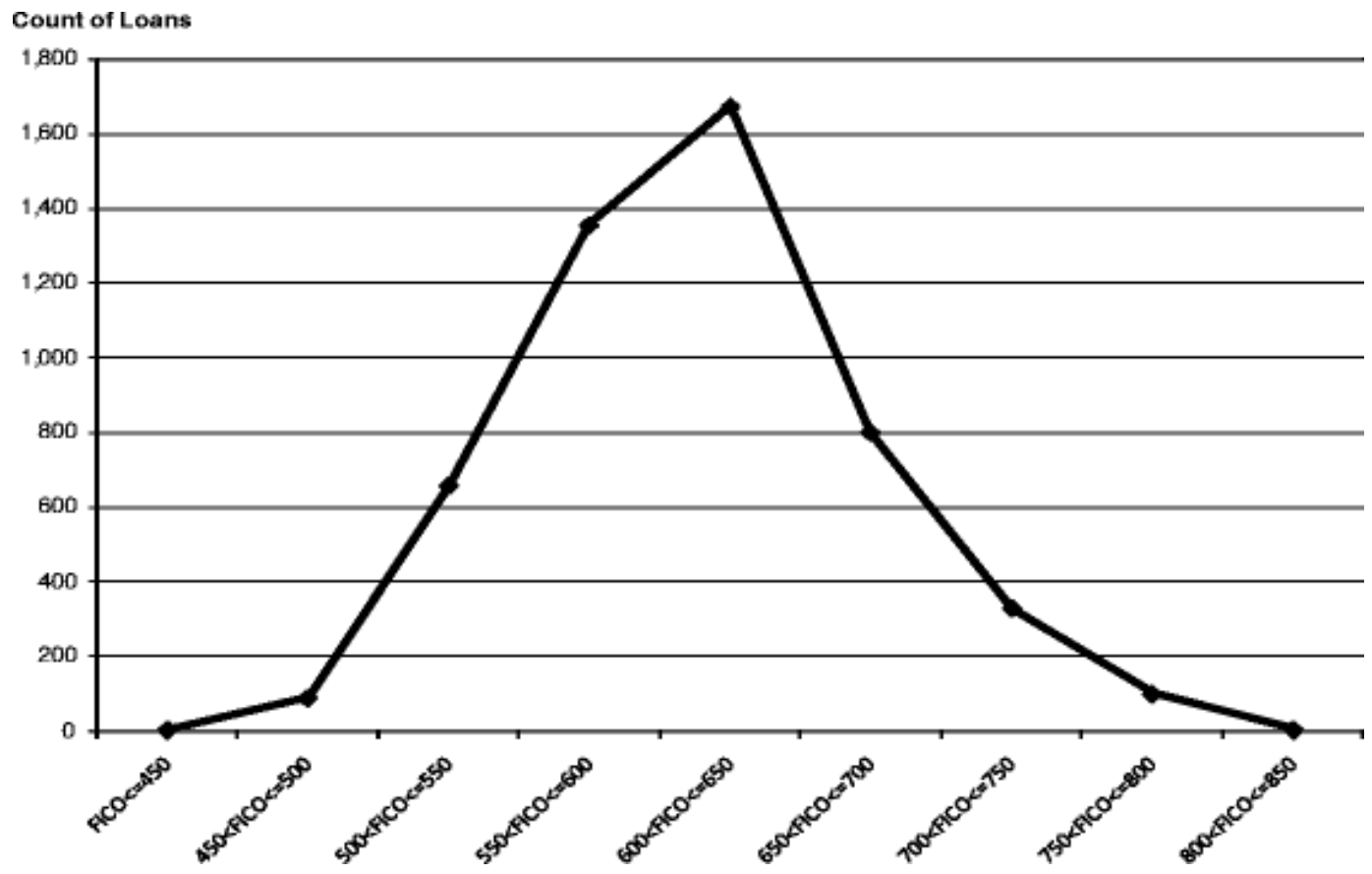

Figure 3. Distribution of history of delinquency. Delinq is the fraction of the loan's life spent in delinquency prior to the beginning of foreclosure proceedings

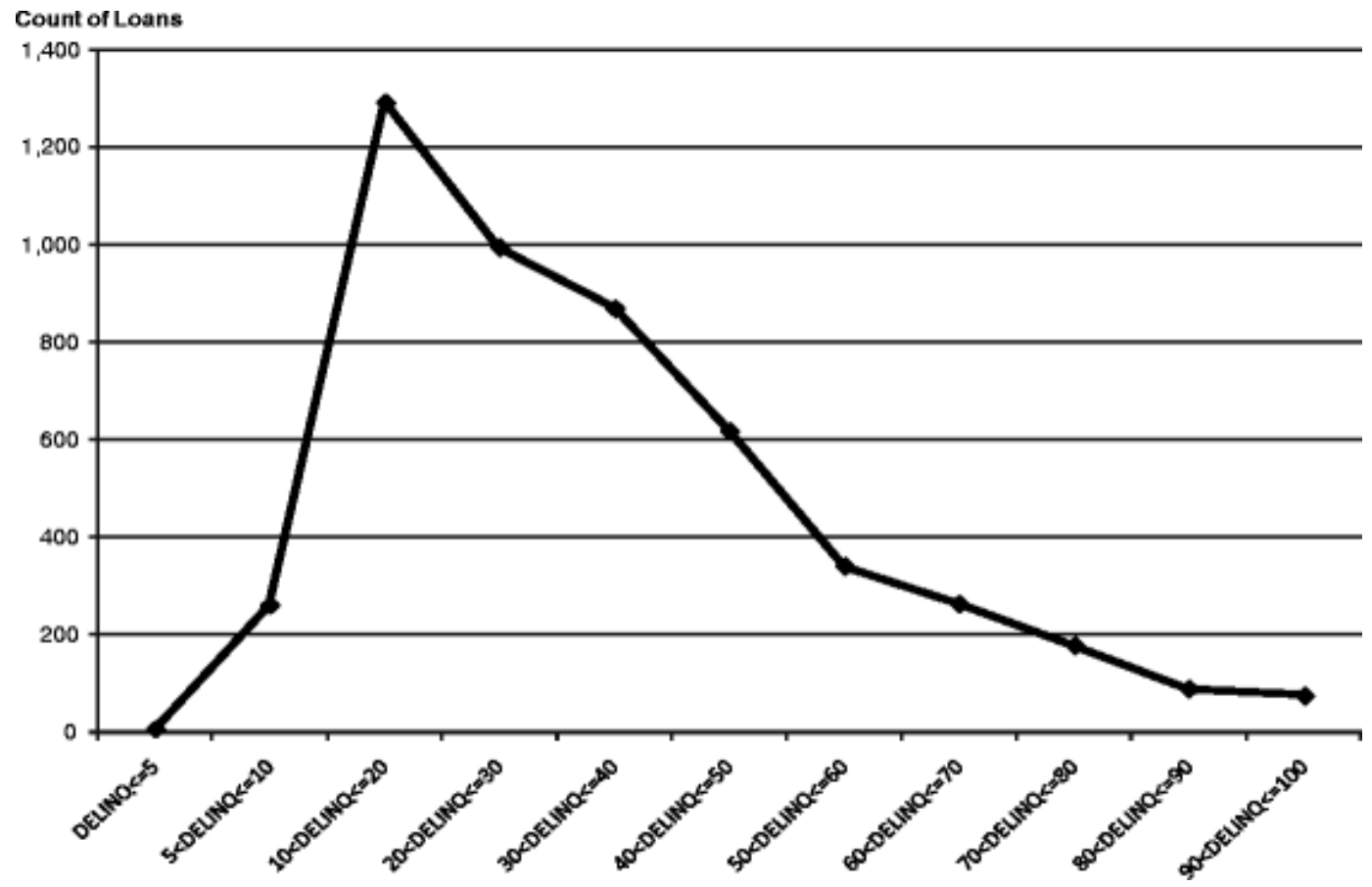

Journal of Real Estate Finance and Economics, Vol. 40, No. 2 (February 2010): pg. 109-129. DOI. This article is (C Springer and permission has been granted for this version to appear in e-Publications@Marquette. Springer does not grant permission for this article to be further copied/distributed or hosted elsewhere without the express permission from Springer. 
NOT THE PUBLISHED VERSION; this is the author's final, peer-reviewed manuscript. The published version may be accessed by following the link in the citation at the bottom of the page.

Figure 4. Cumulative baseline. All other variables are evaluated at their means

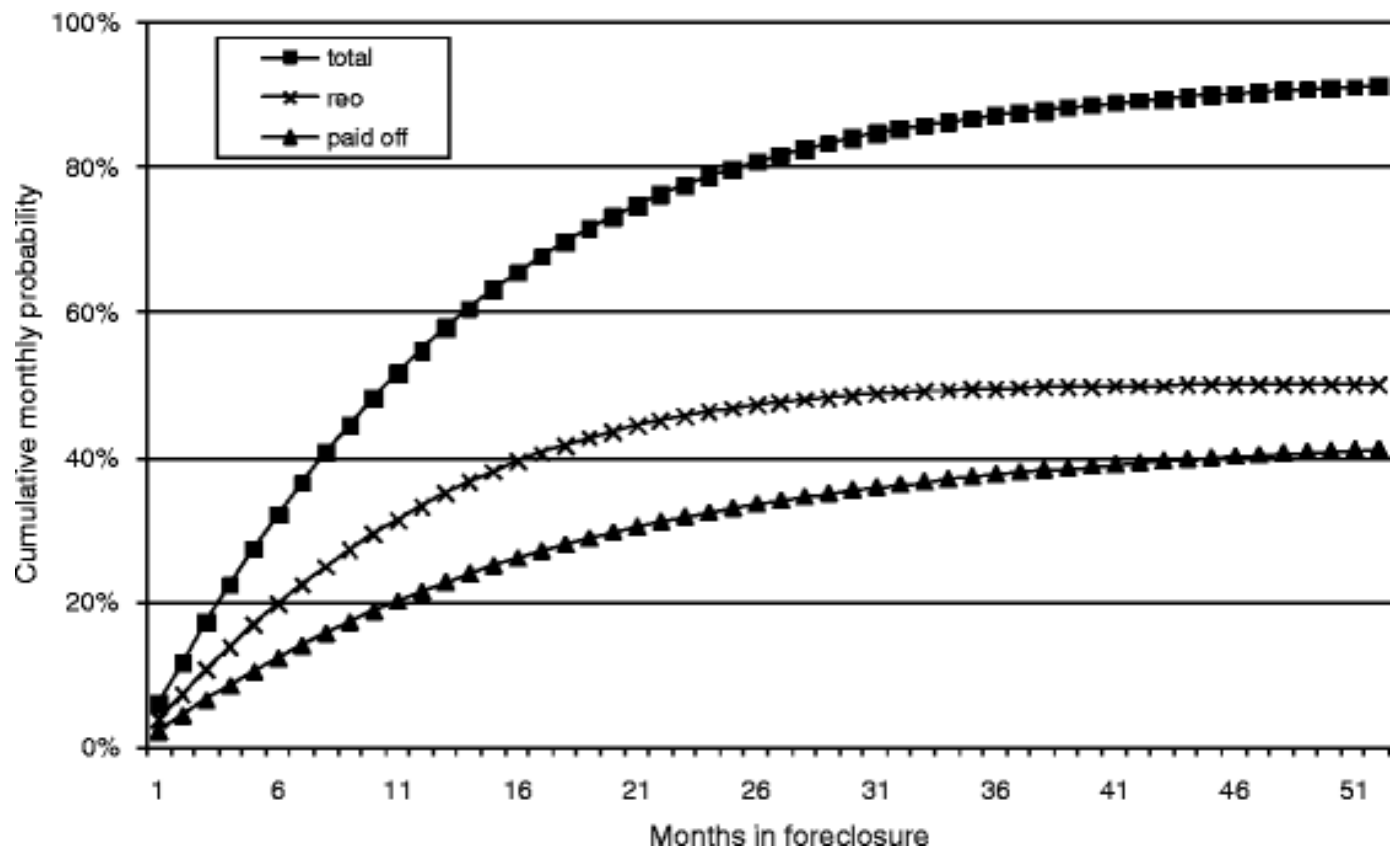

Figure 5. Conditional monthly baseline. All other variables are evaluated at their means

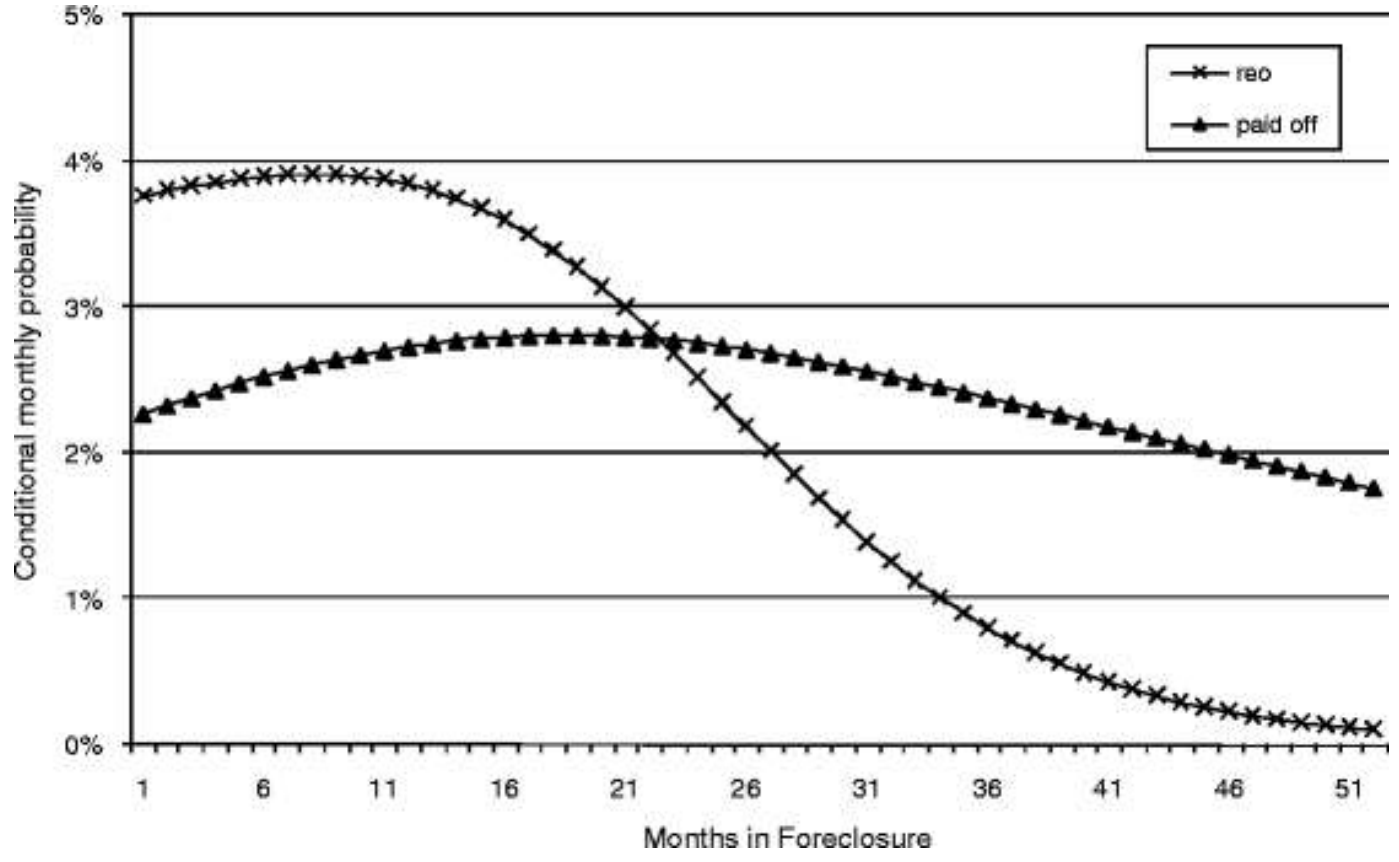

Journal of Real Estate Finance and Economics, Vol. 40, No. 2 (February 2010): pg. 109-129. DOI. This article is (C Springer and permission has been granted for this version to appear in e-Publications@Marquette. Springer does not grant permission for this article to be further copied/distributed or hosted elsewhere without the express permission from Springer. 
NOT THE PUBLISHED VERSION; this is the author's final, peer-reviewed manuscript. The published version may be accessed by following the link in the citation at the bottom of the page.

Figure 6. Probability of exit and the current loan to value ratio. All other variables are evaluated at their means

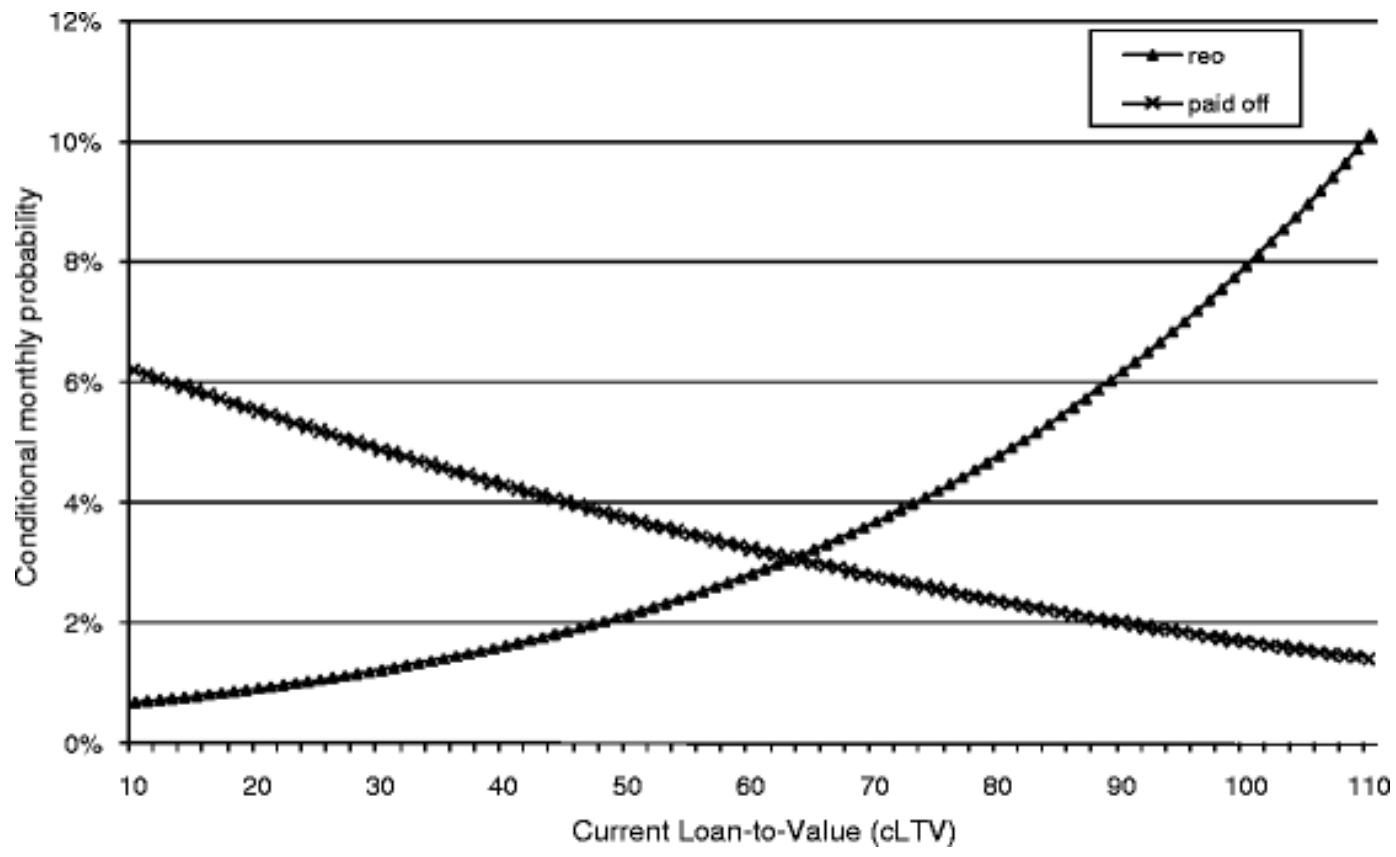

Figure 7. Probability of exit and the credit score at origination. All other variables are evaluated at their means

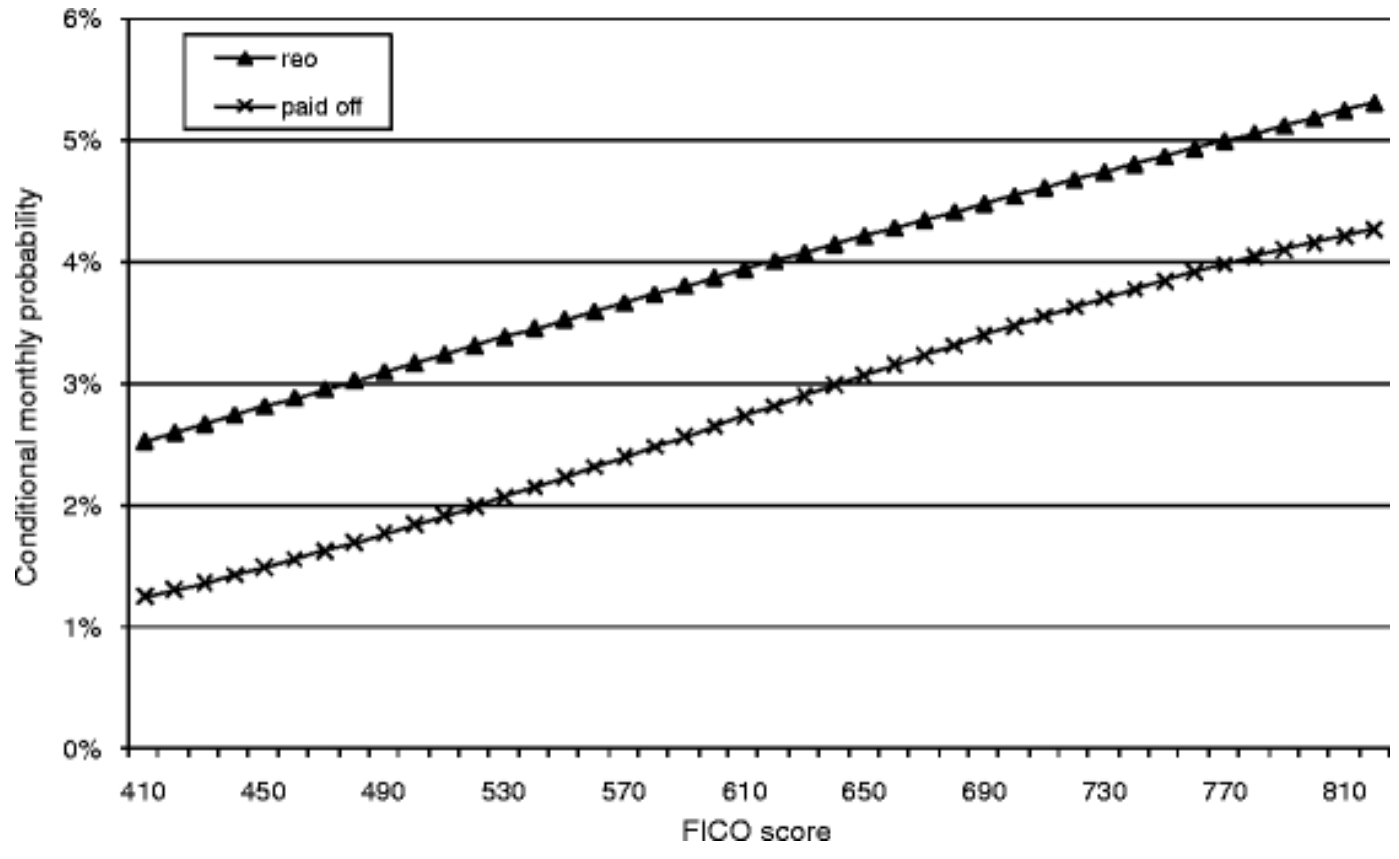

Journal of Real Estate Finance and Economics, Vol. 40, No. 2 (February 2010): pg. 109-129. DOI. This article is (C) Springer and permission has been granted for this version to appear in e-Publications@Marquette. Springer does not grant permission for this article to be further copied/distributed or hosted elsewhere without the express permission from Springer. 
NOT THE PUBLISHED VERSION; this is the author's final, peer-reviewed manuscript. The published version may be accessed by following the link in the citation at the bottom of the page.

Figure 8. Probability of exit and unemployment rates. All other variables are evaluated at their means

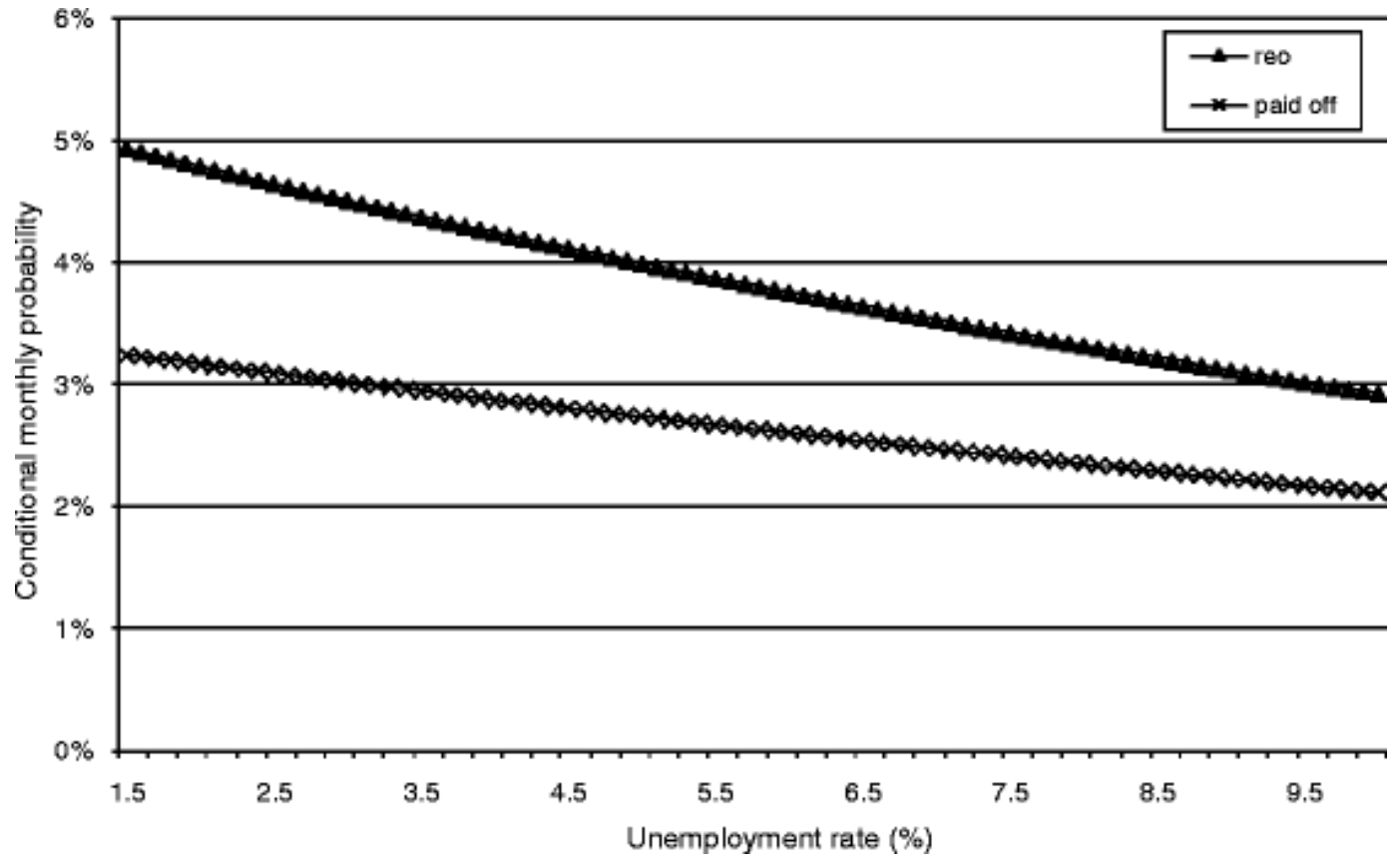

Figure 9. Probability of exit and prior delinquency. All other variables are evaluated at their means

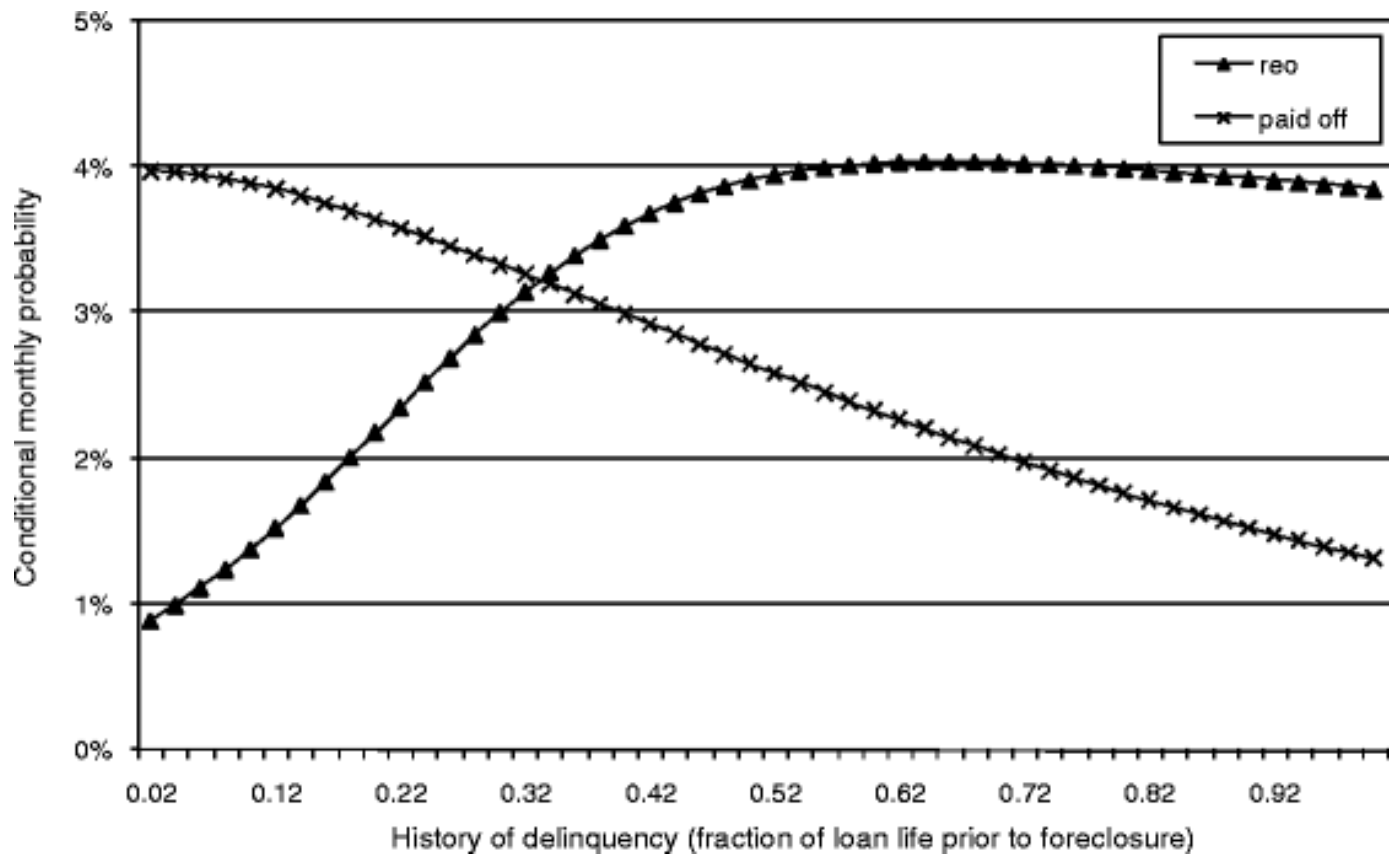

Journal of Real Estate Finance and Economics, Vol. 40, No. 2 (February 2010): pg. 109-129. DOI. This article is (C Springer and permission has been granted for this version to appear in e-Publications@Marquette. Springer does not grant permission for this article to be further copied/distributed or hosted elsewhere without the express permission from Springer. 
NOT THE PUBLISHED VERSION; this is the author's final, peer-reviewed manuscript. The published version may be accessed by following the link in the citation at the bottom of the page.

Figure 10. Probability of exit and interest rates. All other variables are evaluated at their means

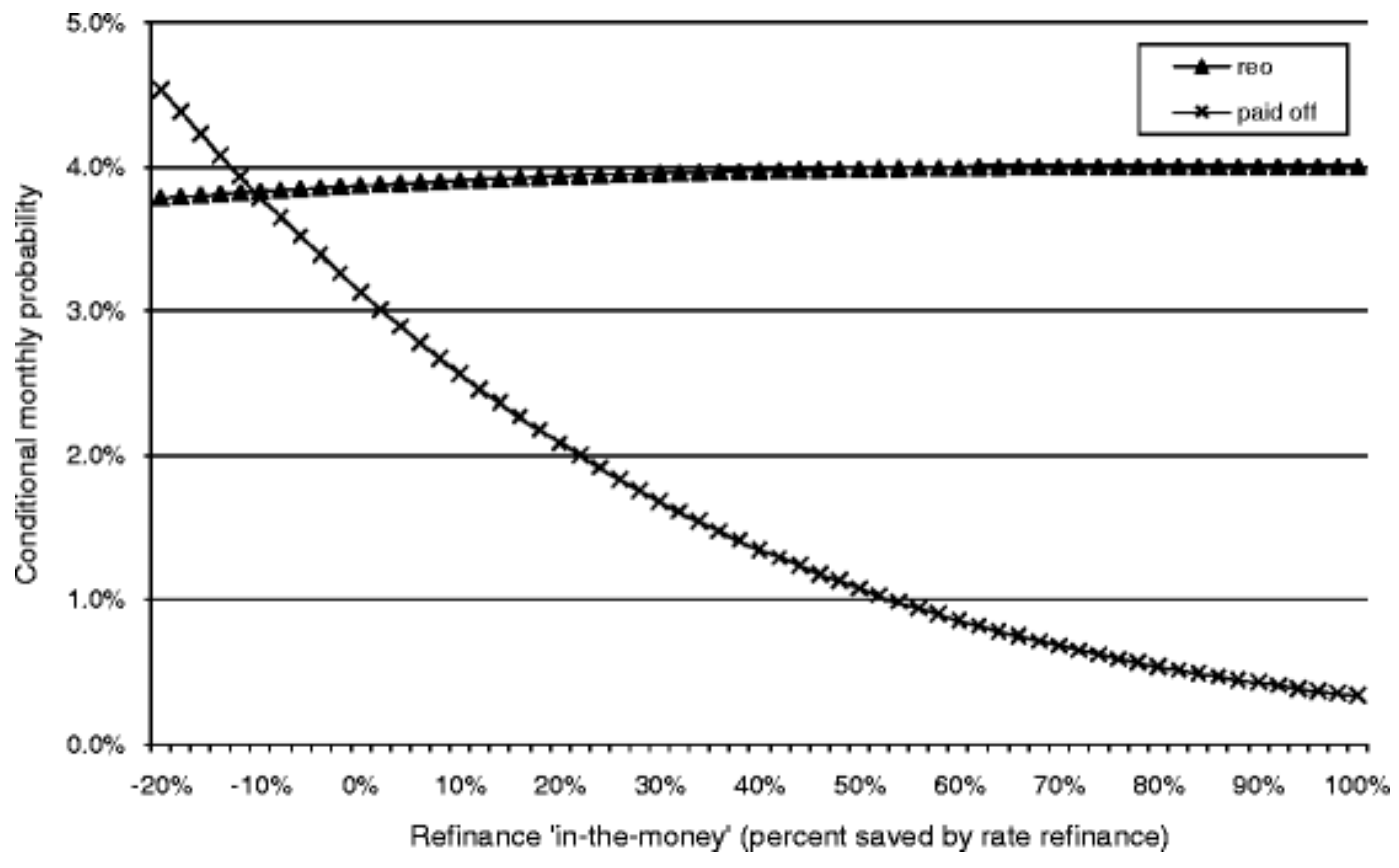

Figure 11. Probability of exit and outstanding balance. All other variables are evaluated at their means

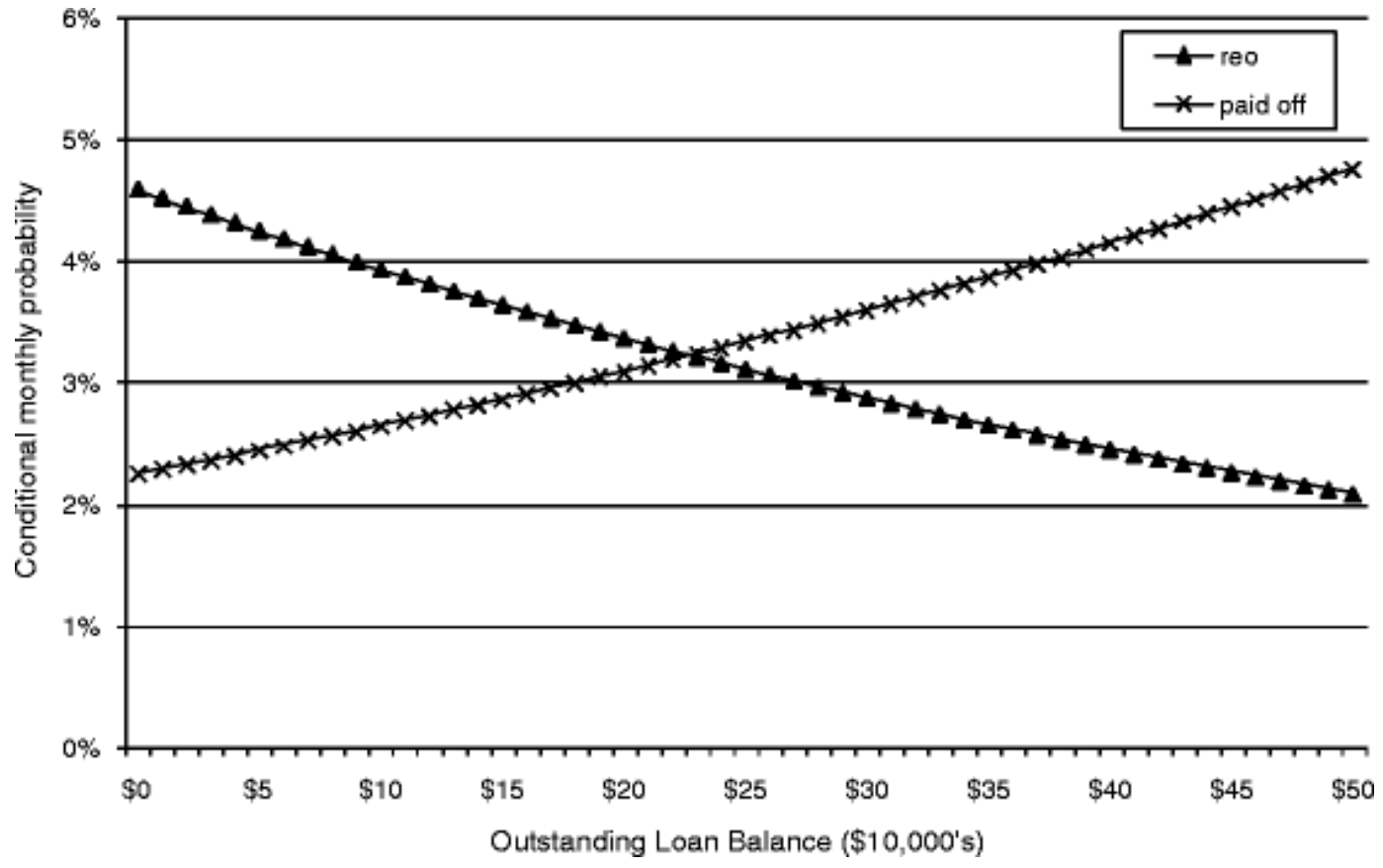

Journal of Real Estate Finance and Economics, Vol. 40, No. 2 (February 2010): pg. 109-129. DOI. This article is (C Springer and permission has been granted for this version to appear in e-Publications@Marquette. Springer does not grant permission for this article to be further copied/distributed or hosted elsewhere without the express permission from Springer. 